\title{
Leadership and Literature: Insights into Shakespearean Tragedies
}

\author{
Shahida \\ Department of Humanities and Social Sciences, NIT, Kurukshetra, Haryana, India \\ *Corresponding Author: shahidakhan27@gmail.com
}

Copyright (C) 2015 Horizon Research Publishing All rights reserved.

\begin{abstract}
In the last few decades, we have witnessed the inclusion of Literature in a variety of disciplines. “Multidisciplinary studies' and 'multiculturalism' being key terms in the academia - chiefly in the Social Sciences and the Humanities - various university disciplines have started strengthening their syllabi in this direction. This paper argues that a single disciplinary approach fails to address a literary tradition and canon in Leadership Studies. It focuses on inclusion of Literature into the discipline. The first part deals with a short introduction on the inclusion of Literature in Leadership studies followed by how Shakespearean texts can be used as case studies to teach leadership issues. The paper argues that literary texts help in developing different perspectives and understanding multiple issues in leadership. A brief review on the theories of leadership is incorporated to enhance the understanding of the essence of leadership. The paper concludes with an emphasis on the inclusion of literary texts in Leadership Studies to promote better understanding of the issues in leadership.
\end{abstract}

Keywords Leadership, Literature, Tragedies, Social Constructionist, Case Study

\section{Introduction}

Leadership Studies as a discipline is of recent origin; however, concepts such as "leading" and "leadership" are relatively old. "Leadership," the term, appears in 1828 in Webster's An American Dictionary of the English Language. But the concept is age-old and is believed to have originated from the beginning of our civilization. Critics may refer to the genesis of the concept of leadership to the times when kings ruled and the times associated with the birth of legends and heroic tales of mythical or real-life heroes. Hence, the genesis of leadership and leaders can be traced from the time of the growth and development of civilizations. The development of the concept has been a process where leaders have laid the foundation of civilizations and they have also been affected by the changes, growth and evolution of those civilizations. Each civilization in the history of humankind has been creative and has had something unique to offer to the study of leadership.

The study of leaders, leading and leadership has been of interest to scholars from various academic disciplines. Leadership Studies has emerged as an independent academic field of study and is also a multidisciplinary field of knowledge enquiry. At the outset, the chief focus is on leadership in the context of organizations and in human life [1]. This is because a single disciplinary approach has failed to address all the dimensions of leading and leadership. Hence, its genesis borrows a lot from other academic disciplines, and both the approaches-social constructionism and essentialism-have impacted upon the discourse in various manners. With this, it has developed as a set of academic pedagogies and the discipline encompasses a host of sub-fields and is filled with definitions, theories, styles, functions, competencies, and historical examples of successful and diverse rulers and leaders. Each discipline has something unique to contribute to the understanding of the concept of leadership, leaders and leading. Earlier Leadership Studies was divided into subgroups, namely, Business Leadership, Educational Leadership and Political Leadership — specifically involving a single disciplinary approach. But in the 1980s, a cadre of academicians, trainers and practitioners rejected the single disciplinary approach to the study and practice of leadership and introduced multidisciplinary approach for its pedagogy. The notable scholars in the field of Leadership Studies include, but are not limited to, Bruce Avolio, Bernard Bass, Warren Bennis, James McGregor Burns, Georgia Sorenson and Barry Posner. Ralph Stogdill's [2] article "Personal Factors Associated with Leadership: A Survey of the Literature" (1948) is cited as an important text in understanding the nature of leadership. Further, Joseph Rost, popular writer and professor at the School of Leadership and Education Sciences, University of San Diego, Victor Vroom, consultant to GE and American Express and professor at the Yale School of Management, have contributed significantly towards decision making and leadership; Gary Yukl [3] professor at the University of Albany, is celebrated as a leading writer on Organizational 
Leadership.

In the last few decades, we have witnessed the inclusion of Literature in a variety of disciplines. "Multidisciplinary studies' and 'multiculturalism' being key terms in the academia-chiefly in the Social Sciences and the Humanities - various university disciplines have started strengthening their syllabi in this direction. Sociology, Anthropology and History, for example, derive a lot of references from the literary world to contextualize histories forgotten or rewritten. So does the newly-developed discipline of Leadership Studies.

This paper argues that a single disciplinary approach fails to address a literary tradition and canon in Leadership Studies. It focuses on inclusion of Literature into the discipline. The first part deals with a short introduction on the inclusion of Literature in Leadership studies followed by how Shakespearean texts can be used as case studies to teach leadership issues. The paper argues that literary texts help in developing different perspectives and understanding multiple issues in leadership.

\section{Method}

The research method consists of interpretation of primary texts by William Shakespeare in the light of issues in leadership put forward in the present decades. I also use historical, philosophical and biographical texts in order to establish that Shakespearean tragedies are helpful in understanding problems in leading. I support my argument with a significant number of texts, critical essays, and books on Leadership Studies and also criticism on Shakespearean plays.

\section{Shakespeare and Leadership Studies}

Including Shakespeare in Leadership Studies, especially in business classrooms, has its own merits. William Shakespeare arguably is one of the leading figures among writers of any generation. Noteworthy to mention here is that from nursery rhymes to school text books, from the mode of teaching poetry to drama, from citing instances of human condition to claiming the art of universality, Shakespeare's works have been popularized throughout the different ages. There have been traditional text books on criticism, children's text book series on Shakespeare's tales, books of erotica based on Shakespearean themes, re-reading and re-writing of Shakespeare and there are multiple versions of Shakespeare's plays. There is also Shakespeare for drama, for comedy, for tragedy, for poetry, for romance, for satire and Shakespeare for post-colonialism and feminism. Numerous other discourses have proved time and again that Shakespeare has achieved an unrivalled status that rarely any other writer has achieved so far. Samuel Johnson [4] places him above all the modern writers. He says, "Shakespeare is above all writers, at least above all modern writers, the poet of nature; the poet that holds up to his readers a faithful mirror of manners and of life". He further declares that Shakespeare aptly imitates essential human nature. His plays depict something which is 'universal' rather than just being a social phenomenon:

His [Shakespeare's] are not modified by the customs of particular places, unpractised by the rest of the world; by the peculiarities of studies or professions, which can operate but upon small numbers; or by the accidents of transient fashions or temporary opinions: they are genuine progeny of common humanity, such as the world will always supply, and observation will always find. His persons act and speak by the influence of those general passions and principles by which all minds are agitated, and the whole system of life is continued in motion. In the writings of no other poets a character is too often an individual; in those of Shakespeare it is commonly a species [4].

There are numerous such instances where Shakespeare is admired, interpreted and used for different situations and purposes. Shakespearean plays have been admired for their plot, characters and poetic quality. Alexander Pope [5], for example, in the preface to The Works of Shakespeare Volume $I$ (1723) writes:

The poetry of Shakespear (sic) was inspiration: indeed, he is not so much an imitator, as an instrument of nature; and it is not so just to say that he speaks from her, as that she speaks through him. His characters are so much nature herself, that it is a sort of injury to call them by so distant a name as copies of her...every single character in Shakespear, (sic) is as much an individual, as those in life itself; it is as impossible to find any two alike.

Harold Bloom [6] goes a step further and gives credit to Shakespeare for "the invention of the human". He asserts that "the early modern English was shaped by Shakespeare; The Oxford English Dictionary is made in his image". He adds further: "Later modern human beings are still being shaped by Shakespeare, not as Englishmen, or as American women, but in modes increasingly post-national and post-gender". Though with the growing popularity of different theories such as Post-Structuralism, Deconstructionism and Marxism, the acclaimed 'universality' of Shakespeare has been put into question, it has proved beneficial to Shakespearean Studies; and what we have instead is there are multiple Shakespeares. In literary analysis, minor characters and figures from his plays have found ample importance in the last few decades. With the rise of sociological theories such as Marxism, Feminism and Cultural Materialism, their significance and sociological structure have been analysed to judge a society or a character so as to centralize the periphery. Psychoanalytic criticism, with the rise of Freudian and Jungian theories, studies and analysis characters, and has furthered the debate to a significant degree where the thought process remains of ample significance. In the Humanities and the Social 
Sciences - as in the case of Literature and Language-Shakespeare has thus established a significant place for himself.

There are multiple reasons for which Shakespeare has been highly popular in the modern era, which may not be documented here in detail. The prominent reasons include, but are not limited to, the use of language and literary expressions, theatrical concepts and dramatic techniques, and above all his characters and themes are of ample importance to the present world.

\section{Theories in Leadership: A Brief Review}

Leadership or leading is a social construct [7-9]. It is discussed as an interactive and complex process where not only a leader affects the followers but the followers also affect him/her. A review of literature reveals an evolving series of schools of thought from the Great Man theory and Trait theory to Transformational leadership. The early theories of leadership tend to focus on the traits, characteristics and behaviour of successful leaders. The traditional approaches to leadership, viz., the Trait approach, Behaviour or Style approach, and the Situational Leadership approach, are criticized in the present generation due to their narrow perspectives which fail to cover all aspects of leadership and leading. It fails on account of lack of empirical evidences to prove that traits and behaviour of leaders are responsible for effective leadership. The traditional theories conceptualize leaders as active players and followers as passive. Chiefly, leaders have been perceived as people with unique traits different from that of followers. Leadership relations are often represented in the context of social hierarchy and usually understood as situations that are socially predetermined. However, later theories on leadership begin to consider the role of followers and the contextual nature of leadership [10]. The contemporary approaches conceptualise leadership as a process of interaction. The recent approaches do not presume the existence of a predetermined situation in which the roles of leaders and followers are clearly distributed according to a formal organizational structure, but it is seen as an interactive process where individuals pursuing particular aims influence each other. Therefore, all members of an organization are capable of being leaders and a formal distinction between leader and follower is not possible in such a situation.

Many new models and approaches to Leadership Studies such as Attribution Theory, Psychodynamic Leadership Approach, Neo-charismatic Leadership, Leader-Member Exchange Theory, Symbolic Leadership, Role Theory of Leadership, Idiosyncrasy Credit Model of Leadership, Micro-Politics Approach to Leadership, and Social Learning Theory of Leadership have come up in the recent times. Consequently, the contemporary approaches to leadership present it as "a sequence of multidirectional, reciprocal influential processes among many individuals at different levels, in different subunits, and within executive" [3]. The focus of all these theories has been on the subjective perception of the individual for developing and forming leadership relations. It is understood as a result of the various interactions among members which is hardly ever predictable. Further, leadership in the present is a sociological process which has evolved with the growth and development of democratic principles.

\section{Discussion}

The study of leadership is incomplete without including Humanities [11]. It is humanities that supplies a rich foundation for understanding the context of leadership and it offers a gigantic repository of information about morality and human behaviour that spans over time and across cultures [12]. Subjects such as History, Literature, Philosophy and Religion offer a rich background for the study of leadership. This is because the aim of liberal arts is to impart "knowledge that is good in itself and to educate citizens to live and make choices in a free society" [12]. Most of the contribution in the growth and development of Leadership Studies comes from Management and Social Psychology but Humanities provides the basis to understand the theoretical aspects. Today many business schools have started including literary texts to teach leadership. For example, in an article entitled "Can Shakespeare Really be a Useful Management Tool?" published in The Independent on 18 January 2007, by Peter Brown draws our attention towards the new Management course called 'Politics, Power and the Art of Influence' launched by the Said Business School, Oxford. In this article he highlights the upcoming trend, among the Management teachers, to use Shakespearean plays for teaching lessons in leadership and management. Designed for experienced executives, it combines Shakespeare's history play, Julius Caesar, role play and modern management theory. This is just one example. There are many management institutes which use literary texts to teach leadership and management. In general, most of the contribution in the growth and development of Leadership Studies comes from Management and Social Psychology but Humanities provides the basis to understand their theoretical aspects.

It is around the end of the twentieth century that management teachers and consultants started exploring works of classics to derive lessons in leadership and management. The real impetus to this new trend came up with the publication of an article entitled "How Business Schools Lost Their Way," in May 2005, in the Harvard Business Review, by two very popular academicians in the field of Leadership Studies, namely, Warren G. Bennis and James O'Toole [13]. Their article created a positive confusion in business schools in relation to the changes needed in the curriculum. Earlier, the focus of Leadership Studies was more on theories than their application in real 
life. The article highlighted the inefficiency of the business curriculum and its inability to cater to the need of students. It argues that business schools have lost their way because of scientific model that dominates business research and teaching leading to strong dependency on theories but its practical application remains ineffective. Executives often fail to apply these theoretical concepts in real-life situations. Therefore, they strongly recommend a course in literature for management students because literary texts can be instructive and helpful in developing insights. It was also realized that teaching business and leadership can be entertaining through fiction.

By the end of the twentieth century, the idea of introducing literary texts among business management students started a new trend in the United States and the United Kingdom, which became popular with the publication of a number of books and articles focusing on literary texts to teach lessons in management and leadership. Paul Corrigan [14] Shakespeare on Management goes on to use Shakespearean plays to demonstrate the psychology of leadership. He explores how Shakespeare through his plays present before us the different roles a leader can take and the different skills needed to be a successful leader. Further, Shakespeare on Management: Wise Business Counsel from the Bard by Jay M. Shafritz [15] explores most popular topics in business, from mergers to acquisitions, and office politics and power plays to public relations. Another important work in this field that holds attention and has become a bestseller is Power Plays: Shakespeare's Lessons in Leadership and Management. It is a joint effort of Tina Packer and John O. Whitney. The writers, highlighting the obvious question of the complexity of assessing Shakespeare in business management, make their methodological clarifications clear and note down the reasons for which Shakespearean Studies remain important:

William Shakespeare as a management consultant? "Nonsense," you say? Not so fast...he is arguably the Western tradition's greatest thinker and student of human psychology. James Joyce once said that after God, Shakespeare has created most. The eminent Yale literary critic Harold Bloom has long argued that Shakespeare's plays can be taken as a kind of secular Bible of modern consciousness.... Bloom even goes so far as to argue in his most recent book, Shakespeare: The Invention of the Human, that by inventing so many deep and diverse characters that have entertained playgoers and readers for almost half a millennium, Shakespeare has, in effect, invented us. [6]

Rationalising Shakespeare, in other words defending literature, has been part of the canon while we frame the pedagogy of Leadership Studies. Notwithstanding the nature of the debate, scholars have extensively dealt with the problem of locating Shakespearean characters and themes in the light of the same. Joseph L. Badaracco [16] , for example, uses works of serious writers as case studies to teach business ethics. In his book Questions of Character: Illuminating the Heart of Leadership through Literature, he argues that literature helps leaders develop personal answers to specific questions. Works of art provide powerful perspectives on fundamental dilemmas faced by managers and executives. For example, Badaracco rationalizes the study of Arthur Miller's play Death of a Salesman (1949) to put forward the two propositions about dreams and generalizes how within our society we have singular or multitude of dreams that take us towards success $(2006,11)$. Citing literary or historical situations, thus, helps us in locating human positions in a better way than reading theoretical lessons about lifestyle.

The trend of using literary texts has attracted many a scholar practicing Leadership Studies in pedagogical endeavour. James G. March [17], for example, provides an innovative contribution to the study of organizations. In a course on leadership at Stanford University he explores the problems involved in leading and leadership using acclaimed works such as War and Peace (1869) and Don Quixote (1605). March uses literature to examine a set of dilemmas related to leadership, and further investigates questions concerning the balance between private life and public duties, ingenuity and innocence, diversity and integration, and the expression and control of sexuality. Warren Gamaliel Bennis [13] in his book On Becoming a Leader (2003) taking a social constructionist approach argues that when we nurture individuals with societal leadership skills, we contribute to their growth of taking responsibilities. This book serves as a beacon of insight, delving into the qualities that define leadership. In India, it is at Indian Institute of Management, Ahmedabad, since 1989, Professor S. Manikutty and Professor S.P. Singh [18] have been teaching a course entitled "Leadership: Vision, Meaning and Reality" based on literature. Though a prototype of imitation, it was first of its kind in India. The course was highly popular amongst graduate students and witnessed some positive changes. They document their experiences of the course and discussions in Essence of Leadership: Explorations from Literature (2010). The book argues that understanding leadership is really about understanding life and this starts with gaining an understanding of the self. They start with Cervantes' masterpiece Don Quixote (1604) highlighting the protagonist's 'high' self-confidence. This is followed by other texts that highlight important issues: ambition and purpose in Chinua Achebe's Things Fall Apart (1958), faith versus reason in Bertolt Brecht's The Life of Galileo (1937-39), awakening the human spirit in Bernard Shaw's Saint Joan (1924), authenticity in Girish Karnad's Tughlaq (1964) and Mudrarakshasa (4 $4^{\text {th }}$ or $5^{\text {th }}$ century) by Visakhadatta, leader and society in Arthur Miller's All My Sons (1947), role of illusions in Ibsen's The Wild Duck (1884) and $A$ Doll's House (1879) and the epic Mahabharata for development of perspective. Its limitations, however, include the incoherent attribution of texts without much methodological clarification plus the way texts of different periods and cultures housed under one category. 
In the last decade literary and historical characters from various texts have been used as pedagogical tools by teachers of business management and leadership consultants; Shakespeare and Shakespearean characters have been extensively used for an understanding of the human condition. Shakespeare's plays are analysed and investigated by the teachers of business management to develop perspectives and find answers to perennial problems that have perplexed even best of leaders. Michael Useem, Director of the Wharton Center for Leadership and Change Management, points out that "by watching how historical figures behave in settings far before our time...we often get very good insights into what is vital in our own leadership or managerial moments". Further, he asserts that "we include Shakespeare in our range of learning experiences because it is one of the more indelible ways we have found of bringing points to life - in part because of the power of his insights and also because of the intrinsic elements of the stories he tells". Hence, introducing Shakespeare has been an in-trend.

Among other practitioners of Shakespeare in business classrooms include Carol Adelman and Ken Adelman, founders of Movers \& Shakespeares [19]. They use Shakespeare's plays to teach modern management skills to executives. Ken Adelman, along with Norman R. Augustine, has authored a book called Shakespeare in Charge: The Bard's Guide to Leading and Succeeding on the Business Stage. It deals with the application of Shakespeare's understanding of palace politics and strategies of warfare to twists and turns of the corporate world. The Ariel Group: Leadership Presence is another international training and consulting firm that uses theater-based, experiential learning techniques to teach business executives how to develop and hone their individual leadership presence. Craig Cochran states that Shakespearean tragic heroes have lots to offer to management students. In the article "A Shakespearean Lesson in Leadership" posted on Inside Quality Insider, he praises Macbeth as a war hero who embodies bravery, resoluteness, and strength - quintessential attributes of good leaders but his downfall points out the pitfalls involved in being over ambitious.

\section{Conclusions}

Thus, introduction of literary texts into business classrooms has become a trend in the modern era. Arguably, this is because literature serves to introduce the basic issues in life which cannot be separated from the issues in leadership. In other words, both the issues of life and leadership are inseparable. If we take an Aristotelian view point, literature introduces us to the imaginary world but it is not far from the real one. Besides, literature also stimulates reflection on the issues of life. Oliver Williams [20], a scholar of religion and business ethics, argues that "stories that 'ring true' bring us in touch with the fullness of our humanity". Aristotle in Nichomachean Ethics claims that the best education should not only impart information but it should also develop our capacity to feel and sympathize because to feel delight and pain rightly or wrongly has no small effect on our actions. Literature is also helpful in arousing awareness regarding those issues which a person may not have experienced directly but needs to be prepared for. Robert Brawer [21] states: "The values and insights we glean from serious literature sensitize us to ourselves and, by extension, to the problems inherent in managing people in an organization". Literature is also popular in Leadership Studies and Business Management classroom because stories or storytelling method is immensely appreciated for being entertaining. Stories open the imaginative side of human mind; Martha Nussabaum [22] suggests that "storytelling and literary imagining are not opposed to rational argument, but can provide essential ingredients in a rational argument". She clarifies the role of literature in rational argument as "an ethics of impartial respect for human dignity will fail to engage real human beings unless they are made capable of entering imaginatively into the lives of distant other and to have emotions related to that participation" (1995, xiv). It is generally observed that speeches by great leaders include storytelling as a strategy to make principles concrete for the followers. The defense of introducing literature in business classrooms continues. Gardner [23] argues that storytelling is a central part of the work of leaders. Howard Gardner asserts that "chiefly through the stories they (leaders) relate" the human condition. Therefore, storytelling and stories have become an integral part of Leadership Studies and Business Management classrooms. Introducing Shakespeare in such classrooms not only helps students understand the basis of his writing, they also understand the human predicament in a different way.

\section{REFERENCES}

[1] Bernard Bass and Ralph Melvin Stogdill. Bass and Stogdill's Handbook of Leadership: Theory, Research and Managerial Applications.Free Press, New York, 1990.

[2] Ralph M. Stogdill, Handbook of Leadership: A Survey of the Literature, Free Press, New York, 1974.

[3] G.A. Yukl, Leadership in Organisations, Prentice Hall, New Jersey, 1994.

[4] Samuel Jonson, Timber or Discoveries Made Upon Men and Matter, Michgan University Press, Michgan, 1892.

[5] Alexander Pope, ed. Preface. The Works of Mr. William Shakespeare. 6 vols. London: Jacob Tonson Press, London, 1723. ix-x.

[6] Harold Bloom, Shakespeare: The Invention of the Human, Penguin Group, New York, 1998.

[7] K. Grint, Problems, Problems, Problems: The Social Construction of Leadership. Human Relations, Vol. 58, No. 112005.

[8] J.R. Meindl, The Romance of Leadership as a Follower Centric Theory: A Social Constructionist Approach. Sage, 
Leadership Quarterly, Vol. 6. No.3, 1995.

[9] S.E. Sjostrand, J.Sandberg and Mats Tyrstrup. Invisible Management: The Social Construction of Management. Thompson Leary Press, London, 2001.

[10] James Macgregor Burns, Encyclopedia of Leadership. 4 vols. Sage, London, 2004.

[11] Joanne B. Ciulla, Ethics and Leadership Effectiveness, Sage, California, 2004.

[12] Werner Jaeger, Paideia: The Ideals of Greek Culture, Oxford University Press, Oxford, 1986.

[13] James O'Toole and Warren Bennis, On Becoming a Leader, Perseus, Cambridge, 2003.

[14] Paul Corrigan, Shakespeare on Management, Penguin Books, New York, 1999.

[15] Jay M. Shafritz, Shakespeare on Management: Wise Business Counsel from the Bard, Harper Collins, New York, 1999.

[16] Joseph L. Badarcco, Questions of Character: Illuminating the Heart of Leadership through Literature, Harvard University
Press, Harvard, 2006.

[17] James March and Thierry Weil. On Leadership. Blackwell, Massachusetts, 2005.

[18] S. Manikutty and S.P. Singh. Essence of Leadership: Explorations from Literature. Macmillan, Delhi, 2010.

[19] Ken Adelman and Norman R. Augustine. Shakespeare in Charge: The Bard's Guide to Leading and Succeeding on the Business Stage, Miramax, California, 1999.

[20] Oliver Williams, Moral Imagination: How Literature and Films can Stimulate Ethical Reflection in the Business World. University of Notre Dame Press, Notre Dame: 1998.

[21] Robert A. Brawer and Bob Brawer. Fictions of Business: Insights on Management from Great Literature. Wiley, New York, 2000.

[22] Martha C. Nussabaum, Poetic Justice: The Literary Imagination and Public Life, Beacon Press, Boston, 1995.

[23] Howard Gardener, Leading Minds: An Anatomy of Leadership, Basic Books, New York 1996.. 